\title{
PERILAKU PENYIMPANGAN SOSIAL PADA KALANGAN REMAJA KELURAHAN AKEHUDA KOTA TERNATE UTARA
}

\author{
Syahril Muhammad ${ }^{1}$, Mhd. Asikin Kaimudin ${ }^{2}$ \\ 1 Staf Pengajar Program Studi Pendidikan Pancasila dan Kewarganegaraan, FKIP-UNKHAIR \\ 2 Mahasiswa Program Studi Pendidikan Pancasila dan Kewarganegaraan, FKIP-UNKHAIR
}

Email: syahrilmuhammad@gmail.com

$\begin{array}{ll}\text { Diterima } & : 08-09-2019 \\ \text { Direvisi } & : 15-10-2019 \\ \text { Dipublikasi } & : 04-11-2019\end{array}$

\begin{abstract}
Abstrak. Penelitian ini bertujuan untuk memecahkan masalah. penilitian ini bertepat pada Akehuda. Terkait dengan tindakan remaja yang bertentangan dengan nilai-nilai adat istiadat dan norma yang berlaku di masyarakat, biasanya di sebut dengan perilaku menyimpang. Penelitian ini merupakan metode kualitatif penelitian dilakukan di Kelurahan Akehuda Kota Ternate Utara. objek dalam penilitian ini ialah Lurah, Tokoh Masyarakatt, Ketua Pemuda, Guru, RT, Ibu/bapak Kos. Jenis Pengumpulan data Melalui observasi, wawancara dan dokumentasi. jenis analisis data ialah reduksi data, penyadian data dan penarik kesimpulan. Hasil penelitian ini menunjukkan bahwa. Perilaku penyimpangan sosial ialah bentuk tindakan yang bertentangan dengan nilai-nilai adat dan norma yang berlaku di masyarakat, seperti miras, tawuran, menjudi, dan narkoba. adapun faktor penyebab terjadinya perilaku penyimpanagan sosial yang di lakukan di kelurahan Akehuda yaitu Faktor keluarga, pergaulan, lingkungan, dan pendidikan, dalam hal ini untuk melakukan perilaku menyimpang. masalah tersebut sudah membawa dampak negatif pada keluarga dan diri sendiri, seperti orang tua di mata masyarakat sangat buruk dan terhina. Dampak dalam diri sendiri pun sangat besar seperti gangguan sikologi dan bahkan ada yang bisa cacat.
\end{abstract}

Kata Kunci: Perilaku menyimpang remaja, adat istiadat, norma dan agama

\section{PENDAHULUAN}

Sesuatu dianggap menyimpang apabila tidak sesuai dengan nilai-nilai dan norma-norma sosial yang berlaku dalam masyarakat atau dengan kata lain penyimpangan (deviation) adalah segala macam pola perilaku yang tidak berhasil menyesuaikan diri terhadap kehendak masyarakat (Taufik Abdullah, 2014).

Perilaku menyimpang pada remaja terjadi pada masyarakat di kalangan atas maupun di kalangan bawah contohnya saja di Keluraha Akehuda. Telah banyak terjadi kasus pergaulan bebas di kalangan remaja dan telah mencapai titik kekhawatiran yang cukup parah, terutama mengomsumsi minuman keras, kedua anak yang merokok di bawah usia 18 tahun, dan mengkomsumsi Narkoba (Bagong Suyanto).

Semakin mudah dan cepatnya arus komunikasi saat ini dapat meningkatkan rasa ingin tahu dan mendorong remaja untuk mencoba sesuatu yang baru dan dapat menjadikan semua itu sebagai pengalaman yang berarti baik yang sifatnya positif maupun negatif. Disebut positif karena dengan adanya arus komunikasi dan informasi yang mudah dan cepat diharapkan para remaja dapat berkarya dan berprestasi lebih. Namun juga bisa menjadi negatif yaitu mendorong remaja untuk berperilaku yang tidaksesuaidengannorma-norma yang ada di dalammasyarakat (Soerjono soekanto).

Pendidikan dalam keluarga sangatlah penting dan merupakan pilar pokok pembangunan karakter seorang anak. Pendidikan dasar wajib dimiliki tidak hanya oleh masyarakat kota, tetapi juga masyarakat pedesaan. Seseorang yang memiliki tingkat pendidikan tinggi cenderung lebih dihormati karena dianggap berada strata sosial yang tinggi. Kualitas seseorang dilihat dari bagaimana dia dapat menempatkan dirinya dalam berbagai situasi. Orang tua seharusnya memahami bahwa merekalah 
sebagai penanggung jawab utama dalam pendidikan putra-putrinya. Dan secara umum, berhasil tidaknya pendidikan seorang anak biasanya dihubungkan dengan perkembangan pribadi orang tuanya dan baik tidaknya hubungan, komunikasi dan role model dalam keluarga (Rustam Hasyim, 2016).

Melalui gambaran tersebut di atas dapat dikatakan bahwa penyalahgunaan narkoba, minuman keras, merokok, dan mencuri adalah tindakan yang bertentangan dengan hukum negara, agama, masyarakat, dan adat setempat. Berdasarkan permasalahan yang dikemukakan tersebut maka penelitian ini menjawab bagaimanakah bentuk perilaku menyimpang di kalangan Remaja kelurahan Akehuda Kecamatan Kota Ternate Utara.

\section{METODE PENELITIAN}

Metode penelitian yang digunakan dalam penelitian ini adalah deskriptif kualitatif. Penelitian kualitatif adalah metode penelitian yang digunakan untuk meneliti pada objek penelitian secara alamiah. Menurut Meleong dalam Sugiyono (2016), penelitian kualitatif adalah suatu penelitian ilmiah, yang bertujuan untuk memahami suatu fenomena dalam konteks sosial secara alamiah dengan mengedepankan proses interaksi komunikasi yang mendalam antara peneliti dan fenomena yang diteliti (Hardiansyah, 2010). Penelitian ini dilaksanakan di kota Ternate kelurahan Akehuda kecamatan kota Ternate Utara dan dilaksanakan pada bulan Mei hingga Juni 2019.

Dalam penelitian ini peneliti menentukan subjek dengan menggunakan teknik Purposive Sampling yakni peneliti berusaha mendapatkan informasi atau data melalui orang-orang yang memiliki kemampuan untuk memberikan informasi yang akurat dan relevan dengan masalah yang diteliti (Iskandar, 2003). Dengan subjek penilitian sebanyak 8 orang, terdiri dari Lurah, Tokoh Masyarakat, Pemuda, Guru, RT, dan Ibu/bapak Kos.

\section{Teknik Pengumpulan data}

Teknik pengumpulan data merupakan langkah yang paling strategis dalam penelitian, karena tujuan utama dalam penelitian adalah mendatakan data. Tanpa memahami dengan baik teknik pengumpulan data, maka peniliti tidak akan mendapatkan data yang memenuhi standar data yang ditetapkan. Sugiyono (2016). Adapun teknik pengumpulan data dalam penelitian adalah sebagai berikut:

\section{a. Observasi}

Nasution (1988) dalam Sugiyono (2016) menyatakan bahwa, observasi adalah dasar semua ilmu pengetahuan para ilmuan hanya dapat bekerja berdasarkan data, yaitu fakta mengenai dunia kenyataan yang diperoleh melalui observasi. Masalah (1995) dalam Sugiyono (2016) menyatakan bahwa melalui observasi, peneliti belajar tentang perilaku, dan makna dari perilaku tersebut.

\section{b. Wawancara}

Esterberg (2002) dalam Sugiyono (2016) wawancara adalah merupakan penemuan dua orang atau pertukaran informasi dan ide melalui Tanya jawab, sehingga dapat dikonstruksikan makna dalam suatu topic tertentu. Jadi dengan wawancara, maka peneliti akan mengetahui hal-hal yang lebih mendalam tentang partisipan dalam menginterpretasikan situasi dan fenomena yang terjadi, di dalam hal ini tidak bisa ditemukan melalui obserfasi (Susan Stainback, 1988 dalam Sugiyono, 2010).

\section{c. Dokumentasi}

Merupakan cara memperoleh data dengan mempelajari, mencatat atau membuat Salinan dari dokumen dan arsip yang berhubungan dengan objek atau permasalahan penelitian (Nasution, 1996 dalam Sugiyono, 2016).

Data yang telah terkumpul dalam penelitian ini kemudian dianalisis dengan pendekatan diskriptif kualitatif. Data yang dikumpulkan pada awal penelitian melalui pengamatan, wawancara, dan dukumentasi langsung dicatat untuk dianalisa. Data dianalisis dengan menggunakan model yang 
dikembangkan. Ada tiga komponen model yang dilakukan dalam menganalisis data kualitatif yaitu; (1). Reduksi Data (data reduction). Kegiatan ini dilakukan oleh peneliti pada alur reduksi data adalah melakukan pemilihan, membuat ringkasan, pemusatan perhatian pada penyederhanaan, dan transformasi data kasar yang muncul dari catatan-catatan tertulis di lapangan; (2), Penyajian Data (data display). Selanjutnya yang dilakukan peneliti pada alur penyajian data adalah peneliti melakukan kegiatan mengumpulkan informasi yang telah tersusun dari hasil reduksi data. Menyajikan data dalam bentuk teks yang bersifat naratif, gambar dan table; (3). Menarik Kesimpulan/Verifikasi (conclusion/ drawing verification). Pada alur akhir analisis data ini adalah menarik kesimpulan dan verifikasi. Kesimpulan yang dikemukakan merupakan temuan akhir dan permanen yang dapat menjawab permasalahan penelitian (Nani I. Rajaloa, Rustam Hasim, 2018).

\section{PEMBAHASAN}

\section{Bentuk Perilaku Menyimpang di Kelurahan Akehuda}

Orang tua harus bijaksana dalam mendidik anak, salah satunya orang tua harus membuat kaidah-kaidah atau norma yang berlaku pada anak yang bersifat terbuka, mengemukakan pendapat, perasaan dan keinginan oleh seorang anak namun orang tua harus melakukan pengawasan terhadap anak. Dimana sikap orang tua juga kurang menghargai pendapat anak remaja maupun sesama anggota keluarga lain, Kurang menghargai adanya karakter atau sikap sesama anggota dalam keluarga, tidak ada musyawarah ketika ada permasalahan dalam keluarga yang bersangkutan dengan anak remaja. Disinilah berdasarkan pengamatan dan hasil wawancara dengan informasiya ternyata orang tua menerapkan budaya-budaya kurang mendidik kepada anak remaja. Sehingga anak remaja merasa trauma atau minder karena pengaruhnya sikologi dan mental pada anak remaja ketika melihat kehidupan teman sebayanya.

Semua perilaku yang dilakukan oleh remaja yang kemudian itu bertentangan dengan norma dan hukum adat yang berlaku pada lingkungan sekitar dikatakan perilaku menyimpang, oleh sebab itu kehidupan anak di kelurahan Akehuda orang tua maupun masyarakat harus melakukan kombinasi dengan pedidikan nilai-nail yang berlaku di lingkungan keluraga maupun masyarakat, agar pola pikir para remaja mengarah pada apa yang diinginkan keluarga dan masyarakat. Kesejahteraan anak adalah suatu tata kehidupan dan penghidupan yang dapat menjamin pertumbuhan dan perkembangan dengan wajar baik secara rohani, jasmani maupun sosial.

\section{Faktor Yang Menyebabkan Terjadinya Perilaku Penyimpang \\ a. Faktor internal}

Faktor-faktor yang menyebabkan perilaku menyimpang antara lain adanya kurangnya pengawasan antara orang tua dengan anak yang menyebabkan anak merasa bebas melakukan aktivitas di luar yang berujung kepada tindakan perilaku menyimpang diluar. Selain itu orang tua masih banyak yang belum mengetahui bahwa anaknya terlibat didalam perilaku menyimpang. Orang tua hanya memberikan rasa kepercayaan kepada anak dan kenyataan pengawasan tidak dilakukan kepada orang tua sehingga anak merasa bebas melakukan segala aktivitas diluar yang berujung kepada tindakan perilaku menyimpang.

Pada sisi lain remaja adalah generasi muda yang berada pada masa transisi untuk mencoba-coba, sikologi remaja pun sagat mudah untuk dipengaruhi. Perkembangan remaja di ikuti dengan rasa ingin mencoba sesuatu yang pernah iya lihat tanpa harus diajak, adapun anak yang di besarkan oleh keluarga yang broken hom, dan tete/neneknya pola pikir anak pun berbeda dengan anak yang sering di besarkan dari orang tua kandungya. Ditambah dengan mudahnya mendapatkan bahan tersebut untuk meraka dikonsumsi. Usia remaja yang masih sangat rentan dalam melakukan perilaku menyimpang, maka harus memberikan perhatian lebih kepada remaja melalui pendidikan formal, informal, dan nonformal. 


\section{b. Faktor Eksternal}

Faktor pergaulan juga menjadi pemicu remaja melakukan tindakan perilaku menyimpang. Remaja dikatakan sebagai masa transisi mencari jati diri mereka. Namun terkadang mereka masih belum mengetahui apa-apa saja dampak yang mereka lakukan dari perilaku menyimpang tersebut.

Sementara hubungan komunikasi dengan anak dalam hal pembinaan, apresiasi sering diberikan oleh orang tua dalam bentuk memberikan hadiah jika anak mendapatkan prestasi. Diskusi juga sering dilakukan oleh orang tua pada saat waktu luang misalnya pada saat makan malam atau waktu santai di rumah. Diskusi yang mereka lakukan antara lain mengenai memberikan gambaran kepada anak mengenai perilaku menyimpang dan memberikan perbandingan kepada anak lain yang mampu menuai keberhasilan hidup sehingga menjadi motivasi anak dalam memberikan diskusi tersebut.

Hukuman yang diberikan oleh orang tua ditujukan agar anak mendapatkan efek jera, namun hukuman yang diberikan oleh orang tua masih digolongkan ringan misalnya jika anak melakukan perilaku menyimpang, orang tua hanya memberikan hukuman berupa tidak diberikannya uang jajan sekolah.

Remaja pada umumnya, lebih suka mencoba hal-hal baru dan banyak remaja yang tidak memikirkan resiko yang diambil jika remaja melakukan aktivitas yang baru didalam hidupnya. Justru jika remaja melakukan kegiatan baru yang positif akan berdampak baik baginya misalnya kegiatan gotong royong, pelatihan kewirausahaan atau kegiatan keagamaan di lingkungannya. Padahal, ajang-ajang seperti ini sangat besar manfaatnya, selain dapat memotivasi untuk berprestasi, juga sebagai ajang aktualisasi diri. Karena sarana aktualisasi diri yang positif ini sulit mereka dapatkan, akhirnya mereka melampiaskannya dengan aksi perilaku negatif yang dapat mengganggu mental diri sendiri dan ketertiban umum.

\section{Dampak Perilaku Menyimpang Terhadap Remaja}

Perilaku meyimpang merupakan salah satu pratek yang sangat sering di lakukan para remaja tanpa mereka pertimbangkan sisi negatif, terhadap apa yang mereka lakukan, sehingga perilaku menyimpang sering terjadi korban terhadap diri sediri. Namun perilaku menyimpag yang dilakukan para remaja berawal dari rasa dorongan diri sendiri, ajakan teman, dan tekanan keluarga sehingga merasa stres sehingga mereka melakukan perbuatan yang bertentangan dengan norma, nilai adat, dan hukum yang berlaku di Indonesia.

Kehidupan para remaja yang sering melakukan perilaku menyimpang sangat memperhatinkan oleh pihak keluarga, karena sering perilaku yang dilakukan para remaja diligkungan pergaulan mereka selalu membawa dampak negatif terhadap nama baik orang tua dan keluarga di sekitarnya conthya seperti merokok, miras, dan narkoba. Remaja yang mengkonsumsi bahan tersebut merasa gelisa jika sudah terpegaruh. Sehingga mereka selalu melakukan terus tanpa harus mereka pertimbangkan dampak dari apa yang mereka lakukan tersebut.

Dalam penanganan sikap dan tindakan remaja yang menyimpang ini merupakan sebuah permasalahan yang berdampak tidak baik untuk kehidupan kita sendiri, keluarga dan masyarakat sekitar kelurahan Akehuda. Dampak pada diri sendiri seperti ganguan sikologi, kita di mata orang tua dan masyarakat di pandang pada sisi negatif. Kemudian orang pun memiliki dampak yang negatif di mata masyarakat, seperti orang tua gagal mendidik anaknya. Begitu juga dengan warga masyarakat sekitar akehuda. Jika remaja melakukan perbuatan yang bertentangan dengan adat dan norma yang berlaku di ligkungan sekitar, maka masyarakat kelurahan lain yang melihat masalah remaja tersebut yang terjadi di Akehuda akan selaulu berpandangan buruk terhadap kelurahan tersebut.

Masalah sedemikian yang sering menjadi serius untuk pihak kelurahan dan keluarga. Karena di balik nama buruk kelurahan dan keluarga, juga merugikan keluarga dalam mengatasi remaja yang mejadi korban dalam perilaku menyimpang. Maka dibutuhkan keseriusan yang lebih maksimal dalam 
menaggulangi sikap remaja dari hal-hal yang tidak kita inginkan. Karena remaja memiliki cita-cita dan masa depan yang sangat tinggi, bahkan kemajuan kelurahan Akehuda berada pada remaja.

\section{KESIMPULAN}

Berdasarkan hasil penyajian data dan pembahasan dapat disimpulkan bahwa perilaku menyimpang sosial ialah bentuk tindakan yang bertentangan dengan nilai-nilai adat dan norma yang berlaku di masyarakat, seperti tawuran, miras, menjudi, menghisap lem, dan obat-obat terlarang. Adapun faktor penyebab terjadinya perilaku menyimpang sosial yang dilakukan oleh remaja kelurahan Akehuda yaitu faktor keluarga, faktor pergaulan, faktor masyarakat dan faktor lingkungan remaja, dalam hal ini untuk melakukan perilaku menyimpang. Masalah tersebut sudah membawa dampak negatif bagi keluarga dan diri sendiri, seperti orang tua dimata masyarakat sangat buruk dan terhina. Dampak dalam diri sendiri pun sangat besar seperti gangguan pisikologi dan bahkan ada yang bisa cacat.

\section{DAFTAR PUSTAKA}

Abdullah Taufik, 2014. Pendidikan Ilmu Sosial: Anni Publishing. Al-Ulum. Azizah, 2013. Kebahagiaan dan Permasalahan Di Usia Remaja: Madrasah Barker Chris, 2011. Cultural Studies, Teori dan Praktik: Kreasi Wacana Dewi Wulansari, 2009. Sosiologi Konsep dan Teori:Refika Aditima Elfiadi Novi, 2013. Perilaku Meyimpang Mahasiswa UNP Dalam Memanfaatkan Ginsberg Morris, 2003. Keadilan Dalam Masyarakat: Pondok Edukasi Herdiyanto Sigit dan Romahdona Syahri Elfi, 2017. Remaja dan Perilaku Huda, 2013. Pertumbuhan fisik dan Perkembangan Intelek Usia Remaja: Hurton B. Paul. Hunt L Chester, 1990. Sosiologi, Jilid 2 Edisi keenam: Erlangga

Kim Woong So, 2011. Kebijakan Hukum Pidana Dalam Upaya Penegakan Hukum Lingkungan Hidup: Universitas Diponegoro.

Nani I. Rajaloa dan Rustam Hasim, "Manajemen Perencanaan Dan Rekrutmen Tenaga Pendidik Oleh Dinas Pendidikan Kota Ternate”, Dalam Jurnal Edukasi FKIP Unkair. Vol. 16 No.1 Januari 2018.

Nurwahida, 2017. Usia Anak Dan Remaja Dalam Perbuatan Perdata Dan Pidana Pada Perilaku Menyimpag Remaja: SMP Negeri 1 Piyungan Bantul. Perpuatakaan: FIS Universitas Negeri Padang.

Pratiwi Hadi Poerwanto, 2012. Kehidupan Sosial Manusia: FIS UNY.

Purwanto Ngalim, 2013. Psikologi Pendidikan: Rosdakarya-Bandung

Putro Zarkasih Khamim, 2017. Memahami Ciri dan Tugas perkembangan Remaja:FITK UINSK. Indonesia

Rohaningsi Sri Nunung. 2014. Dampak Pergeseran Fungsi Dan Peran Keluarga

Rustam Hasyim, “Peranan Orang Tua Dalam Pembentukan Moral Siswa di SD Negeri Tabam Kecamatan Kota Ternate Utara, dalam Jurnal PEDAGOGIK, FKIP Unkhair 2016.

Sarwono W. Sarlito, 2015. Psikologi Remaja: Rajawali Pers

Soekanto Soerjono, 2009. Sosiologi keluarga: Rineka Cipta

Suyanto Bagong, 2016. Masalah Sosial Anak:Prenada media Group 